\title{
RETURNING RESPONSIBILITY TO THE HOME: OUTCOMES OF BACKGROUND CHECKS ON LOW AND HIGH ACHIEVERS IN MIDDLE BASIC MATHEMATICS IN NORTH BANK SUBURB OF MAKURDI, NIGERIA
}

Joshua Abah Abah ${ }^{1 凶}$, Terungwa James Age ${ }^{2}$, Mercy Onyinyechi Okoronkwo²

${ }^{\bowtie 1}$ Department of Science Education, University of Agriculture, Makurdi, Nigeria, abahjoshua.a@gmail.com

${ }^{2}$ Department of Science Education, University of Agriculture, Makurdi, Nigeria

\author{
Highlights \\ - $\quad$ There is a relationship between home involvement and mathematics achievement \\ - $\quad$ Family members and close family members play a vital role in providing guidance for mathematics home work \\ - $\quad$ Parents of pupils in North Bank suburb have shortcomings as mathematics resources providers
}

\section{Abstract}

This study is a correlational survey of the impact of home involvement on the mathematics achievement of Basic 5 pupils in North Bank suburb of Makurdi, Benue State, Nigeria. The study is the outcome of the first phase of a local intervention programme targeted at encouraging homes in the suburb to actively support the mathematics education of children at the Basic Education level. The participants of the study comprise 73 Basic 5 pupils along with their parents across three basic schools in the suburb. The mathematics achievement scores of the pupils for the First Term of the 2016/2017 Academic Session were correlated with home involvement scores generated from the adopted Parental Involvement Questionnaire. The correlational analysis established a weak positive relationship $(r=0.0177$, $p=0.9241$; and $r=0.174, p=0.2884$ ) between home involvement and mathematics achievement. Further interaction with pupils revealed that outside pupils' parents, certain friends, members of extended family and neighbours play vital roles, ranging from re-teaching class work at home to providing guidance for mathematics homework.

\section{Keywords}

Mathematics education, mathematics resource provider, North Bank Makurdi, parental involvement, school-home partnership
Article type

Full research paper

Article history

Received: February 11, 2018

Received in revised form: May 21, 2018

Accepted: May 29, 2018

Available on-line: June 30, 2018

\begin{abstract}
Abah J. A., Age T. J., Okoronkwo M. O. (2018) "Returning Responsibility to the Home: Outcomes of Background Checks on Low and High Achievers in Middle Basic Mathematics in North Bank Suburb of Makurdi, Nigeria", Journal on Efficiency and Responsibility in Education and Science, Vol. 11, No. 2, pp. 29-37, online ISSN 1803-1617, printed ISSN 2336-2375, doi: 10.7160/eriesj.2018.110202.
\end{abstract}

\section{Introduction}

The home is the first social institution of the child. It is where the child first learned the essentials of life such as language, relationships and societal norms and values. The home is the fundamental unit of human society. So, if education is considered as the conscious effort of the society to communicate its culture, science and technology to its young ones, then it is reasonable to see the home as both the first school and the sole beneficiary of other educational endeavours. This implies that the home is an indispensable stakeholder in the education of the child, particularly in the area of mathematics.

One of the renditions of the term "home" indicates that it is one's own dwelling place; the house in which one lives; especially the house in which one lives with his family; and the habitual abode of one's family (CrumpledApp, 2015). Such definitions often lead many to think the term "family" is synonymous with "home". Across much of Africa, particularly in Nigeria, both terms are used interchangeably, considering the fact that extended family practices are common. A child staying hundreds of kilometers from his birth place normally considers the relatives he or she is staying with as family and as such his or her home. Glaringly, in this setting, the duties of a parent and a guardian are one and the same. It is, thus, common for schools to address end-of-term correspondence with the salutation "Dear Parent/Guardian".

Evidently, the home and the school are partners in the growth and development of the child. It used to be normal to accuse the home when children behave out of tune in the public. Awareness of this sense of responsibility has continued to keep the home on its toes to instill in the child the right values and morals right from a very tender age. Such informal training yields outcomes that are often considered as future determinants of progress in areas such as job, marriage and civic responsibility. The traditional African child is trained to protect and preserve the image of his or her family wherever he or she goes to in life. But over the years, the dominance of formal education over home training is beginning to dampen the significance of this sociocultural perspective to education. Many homes misinterpreted emphasis on early childhood education to imply a relief of the burden of providing the core parental support in the upbringing of their children.

With the cost of schooling skyrocketing across Nigeria, homes that could send their wards to good schools kept pushing for real value while continuously relinquishing their traditional roles as the base of children's education. The outcome of this societal pressure on schools is a lopsided educational system that keeps grappling with monumental challenges, most of which are attributable to the host society. Misinformation about the fundamental issues emerging from the loss of collective responsibility has led to educational policies that attempt to control teachers through conceptualizing them as mere technicians who require taming and has resulted in several restructuring that were actually done to teachers rather than with teachers (Lingard, Hayes \& Mills, 2003). The sure path to growth and success in this regard is a co-ordinated participation beginning with the support of parents and the communities to schools by preventing student absence and motivating students 
to learn, do their homework and use their time effectively (Bibiire \& Omojokun, 2016).

An area that requires active participation of the home is the mathematics education of children. Mathematics as a subject is essential for children to appreciate the beauty of nature, think logically and make sound judgment (Iji, Abah \& Anyor, 2018). The home should show some concern and willingness to act in order to correct accumulated myths about the difficulty of mathematics as a school subject and avoid the influence of faulty foundations in mathematics that may impede children's future development. With adequate support from the home, pupils can be encouraged to master the automatic procedures, skillful manipulations and the sense of logic that mathematics is known for (Iji, Abah \& Anyor, 2017).

There seem to be abundant researches into the need for schoolhome partnership in mathematics education as affirmed by Cai (2003), but very few are domestic enough to consider the existing societal dynamics of the current era. Jackson and Remillard (2005) for instance, examined how African-American mothers from low-income neighbourhood of the United States conceptualized their roles in their children's mathematics learning with their findings identifying challenges that are due in part to stereotypes held by practitioners about the families they serve in low-income urban schools. The incidences of social and economic variables on education of poor communities are well documented in available literature (Jimenez Bandala \& Andrade, 2017; Husak \& Hudeckova, 2017; and Safrankova \& Zaptopkova, 2017). A local study by Agada (2017) also threw more light on the short-comings of dwellers of slum communities in Makurdi, Benue State, Nigeria, in terms of provision of support in the mathematics education of children. The emerging trend observable from the local community and the incessant cries of local school administrators about the lackadaisical attitude of homes towards mathematics in particular, formed the basis for this study. Specifically, this study is a fact finding survey of the relationship of pupils' home background to their academic achievements in middle basic mathematics, with respect to the peculiarity of the North Bank suburb of Makurdi, Nigeria.

\section{The Role of the Home in Mathematics Education}

One of the reasons the whole world is attracted to the educational system of Finland is the sense of responsibility shared by all stakeholders in the upbringing of children. Coughlan (2016) reports that one of the most striking facts about Finnish schools is that their students have fewer hours of instruction and observe long summer holidays, apportioning bigger roles to the home. The Finnish system adopts a holistic approach to education with parents wanting a family-friendly approach that also holds high respect for teachers. Coughlan (2016) adds that the Finnish school system is inseparable from the culture which it serves. In this sense, children's education is continuous based on the full involvement of the home and the outcome is a fine balance between quantity and quality.

Homes and families have the direct and lasting impact on children's mathematics learning and development of social competence. When parents are involved, pupils achieve more, exhibit more positive attitudes and behaviour, and feel more comfortable in new settings (Adams \& Baronberg, 2011). One of the best things parents can do to improve their children's mathematics literacy is to regularly expose them to practical applications of mathematics at home which can help them develop mathematical reasoning (Kormanik, 2012). The home can help pupils merge what they observe, discover and learn outside the classroom with the theoretical and abstract mathematics they learn in school. Such practical mathematics is readily available in the estimation of resources at home, the use of money for daily expenditure, available games in the community and even in the cultural practices of the society (Abah, 2017; Abah, 2016).

Apart from normal activities in the home, parents and guardians can work with children's school teachers to facilitate their children's mathematics learning. Hartog and Brosnan (2008) identify two reasons why parents-teachers collaborations are likely to be the most profitable. First, children generally want to please both their parents and their teachers. If they see that mathematics is important to both their parents and their teachers, they will consider it important for themselves too. Second, extending mathematical concepts from the classroom to the home will establish the idea that mathematics is not just a school subject, but an everyday subject that makes life more interesting and understandable. Hartog and Brosnon (2008) suggested that teachers can provide assistance in:

i. Setting up a system of home study;

ii. Helping parents understand the sequencing of mathematical skill development;

iii. Suggesting materials and activities that are entertaining and suitable for their child's level and which can be done in a reasonable amount of time;

iv. Providing clear guidelines on how to use materials;

v. Giving feedback on the successes and failures of home activities; and

vi. Knowing when to stop working with a child on an activity so that a good working relationship is maintained.

Generally, emphasis on the role of the home in mathematics education of children dwells on the need for parents and guardians to give more time to children, providing them a supportive environment at home, encouraging their mathematics learning and discussing with them about their problems in the subject. Parents are to keep watch on the children's activities, help improve their study habits and maintain a positive disposition while advising them. Even for parents who themselves found mathematics difficult, there should be a decisive effort to set aside such distaste, avoid talking negatively about the subject, and seek collaboration to instill the love of mathematics in their children (Brown, 2016).

\section{Some Empirical Studies}

Generalizations about the significance of parents' involvement in mathematics education are often rooted in empirical research findings. These studies, though from very diverse demographic backgrounds, are unanimous in affirming that active participation of homes is always favourable to the overall progress of children in academic work. The studies highlighted are only representative of the available literature in this subject. In a Canadian study, Leferre et al. (2009) attested that children's numerical competence in Kindergarten is highly predictive of their acquisition of mathematics in later levels of education, suggesting that experiences at home before schooling are important in understanding how numeracy develops. The researchers correlated the mathematical skills of 146 children in Kindergarten, Grade 1 and Grade 2 with the frequency with which parents reported informal activities that have quantitative components such as games, shopping and cooking. The findings 
of the study showed a relation between parents' reports of their children's participation in mathematics-related activities and the children's mathematical outcomes.

Similarly, Lore, Wang and Buckley (2016) reported a favourable empirical evidence for cultivating a collaborative, home-school relationship aimed at improving the mathematics performance of catholic school first grade students by training parents as providers of at-home numeracy support. The participants included 60 parents from diverse racial backgrounds from two urban catholic schools. The result revealed that students who received the parent-child home numeracy intervention made large and statistically significant gains in their mathematics achievement, measured by a standardized test, as compared to the control group.

A small-scale study by Rockliffe (2001) explored some of the major influences affecting parental participation in mathematics education and examined the changing nature of the role adopted by parents as their children moved up through the school grades. The study observed that the nature, style and strategies adopted by the parents were influenced by factors relating directly to the parents' own mathematical experiences. In contrast to the range of parental responses, the study reported that teachers tended to view the parents as a homogenous group, generally lacking confidence and expertise in mathematics. The outcome of Rockliffe's work points to a high need for more inclusive school practices for encouraging active participation by parents in mathematics education for the overall benefit of the children. Another survey by Bicknell (2006) evaluated New Zealand parents' roles as motivators, resource providers, monitors, mathematics content advisers and mathematics learning advisers. In the study, 18 students (2girls, 12 boys) from a Year6 pullout programme, 10 Year-6 students (2girls, 8 boys) from regular classes in two different schools and 5 Year-8 ( 2 girls, 3 boys) from a full time special class for gifted students, were isolated to examine parental roles in their mathematics achievement. Responses to questionnaire and interviews shows that overall, parents in the study have strong positive attitude about parental involvement. They showed a strong acceptance for the important role that mathematics plays in the children's futures. The parents also rightly recognized the teacher as a key factor in the children's interest, excitement, fascination and appreciation for mathematics.

In a similar vein, Berkowitz et al. (2015) in a randomized field experiment of 587 first-graders, tested on educational intervention designed to promote interactions between children and parents relating to mathematics. The researchers predicted that increasing mathematical activities at home would increase children's mathematical achievement at school. The intervention which involved short numerical story problems delivered through an iPad app, significantly increased children's mathematics achievement across the school year compared to a reading (control) group, especially for children whose parents are habitually anxious about mathematics.

The emerging paradigms and suggestions of these and other studies in their class point to the fact that parental involvement is a process that required school leaders, teachers, students and significant others in the school community to make efforts through consultation, planning and reflection (Bicknell, 2006). The current study is a brain-child of several calls to refine home intervention programmes that appeal to the socioeconomic diversity of homes and the possibility of transforming ordinary out-of-school activities into rich mathematics learning experience for children. A unique feature of the present study is its encompassing dimension which attempts to compare home parameters of high mathematics achievers to that of low achievers. The audacity to confront North Bank suburb dwellers with the friendliness of school-home partnership introduces techniques and approaches that are novel in this part of the world.

\section{Research Questions}

The following questions guided this study:

i. To what extent are homes in North Bank suburb of Makurdi, Nigeria, involved in the mathematics education of pupils at the Middle Basic level?

ii. What is the relationship between home involvement and mathematics achievement of low-achieving pupils at the Middle Basic level in North Bank suburb of Makurdi, Nigeria?

iii. What is the relationship between home involvement and mathematics achievement of high-achieving pupils at the Middle Basic level in North Bank suburb of Makurdi, Nigeria.

\section{Research Hypotheses}

The following hypotheses were tested at 0.05 level of significance

i. There is no significant difference between high and low achievers in the level of home involvement in the mathematics education of pupils at the Middle Basic level in North Bank suburb of Makurdi, Nigeria.

ii. There is no significant relationship between home involvement and mathematics achievement of lowachieving pupils at the Middle Basic level in North Bank suburb of Makurdi, Nigeria.

iii. There is no significant relationship between home involvement and mathematics achievement of highachieving pupils at the Middle Basic level in North Bank suburb of Makurdi, Nigeria.

\section{Materials and Methods}

This study is the outcome of the first phase of a local intervention programme targeted at encouraging homes in the North Bank suburb of Makurdi township to actively support the mathematics education of children at the Basic Education level. The schoolhome partnership for mathematics education (SHPME) project seek to first identify the existing structure of home involvement in mathematics education in the community before providing intervention training and support materials to families identified as critically in need of help. A similar scheme could be found in the descriptions by Lore, Wang and Buckley (2016).

The design adopted for this study is the ex post facto research design. The pre-existing groups in this study are high mathematics achievers and low mathematics achievers. They are compared on achievement in Middle Basic Mathematics as dependent variables on the basic home involvement in mathematics learning. The ex post facto research design compares two or more groups of individuals with similar backgrounds who were exposed to different conditions as a result of their natural histories (Psychwiski.com 2016).

The participants in this study 73 Primary 5 (Basic 5) pupils along with their parents/guardians. The pupils are purposively drawn from 3 Mission Nursery and Primary schools in North Bank suburb of Makurdi, Benue State, Nigeria. Mission schools, which are educational institutions owned and managed by religious missions or churches, were considered appropriate for the kick-off of the SHPME based on their affordability in terms of 
fees charged and their high level of absorption of children from diverse socio-economic background in the local community. Primary 5 was selected for the study because it is a pivotal stage of the Nigerian 9-Year Basic Education system from where pupils are at liberty to transit to the Upper Basic level (Junior Secondary School). Also, pupils in Primary 5 are expected to be able to communicate their feelings about their home conditions during interaction with teachers and researchers.

The procedure for the study involves four distinct stages. The first stage is the recording of the pupils' examination scores in mathematics for the First Term of the 2016/2017 Academic Session. This is handled purely by the partnering schools to establish a measure of academic achievement for each pupil. The second stage involves the ranking of the end-of-term mathematics scores of all the pupils in the selected class of each participating school. The essence of the ranking is to divide the class into two categories, namely high achievers and low achievers, based on pupils' scores. The end of term scores is the overall measure of academic achievement which is summed from scores from all mode of assessment used in the term.

Table 1 shows the descriptive statistics of mathematics scores of pupils in the two categories. The difference in the mathematics scores of pupils in the two categories is significant $(p<0.0001)$ as established from a preliminary $t$-test of the two categories of scores.

\begin{tabular}{|l|c|c|}
\hline \multicolumn{1}{|c|}{ Statistic } & $\begin{array}{c}\text { Math Score of Pupils in } \\
\text { Top Categories }\end{array}$ & $\begin{array}{c}\text { Math Score of Pupils in } \\
\text { Bottom Category }\end{array}$ \\
\hline Data size $(\mathrm{n})$ & 39 & 34 \\
\hline Mean & 67.487 & 37.971 \\
\hline Error & 1.817 & 1.833 \\
\hline SD & 11.348 & 10.690 \\
\hline Skewness & -0.120 & -0.164 \\
\hline Kurtosis & -1.254 & -1.310 \\
\hline $\begin{array}{l}\text { Anderson-Darling } \\
\text { Normality test } p \text {-value }\end{array}$ & 0.4743 & 0.6255 \\
\hline
\end{tabular}

Table 1: Descriptive Statistics of the Two Categories of Pupils

The third stage of the study involves interactions with pupils to obtain general background information of home conditions in relation to the learning of mathematics. This interaction was coordinated by the researchers in collaboration with the schools' head teachers and Primary 5 mathematics teachers. In the fourth stage, parents were sent the second instrument through their wards to fill and return to the mathematics teachers.

Two separate instruments were used for data collection in this study. The first is a researcher designed structured-interview used in the interaction with the participating pupils. The short interview comprises questions like "Do you like mathematics?" Depending on the pupils answer, the follow up question would demand a reason. Other items on the interview template are "Do you normally practice mathematics at home?"; "Who normally assist you in studying mathematics at home?" (to indicate relationship); "How does the person (name or indicated relationship) assist you?"; "Are you doing well in mathematics in school?"; and "What do you think will make you perform better?"

The second instrument used for data collection in this study is a full adoption of the Parental Involvement Questionnaire (PIQ) designed and validated in the work of Cai (2003). The reported reliability coefficient of the PIQ is 0.89 . The PIQ is a 23-item self-reported questionnaire meant to elicit responses from parents on the extent of their roles in the mathematics education of their children.

Table 2 shows the description of the five parental roles and their general descriptions. The items are rated on a four-point Likert-type scale with strongly Agree $=4$, Agree $=3$, Disagree $=2$ and Strongly Disagree $=1$. Conversely negatively worded items are reverse-coded. The benchmark of acceptance is 2.50 implying that a mean below 2.50 indicate rejection (low parental involvement) while a mean of 2.50 and above indicated parent acceptance (high parental involvement).

\begin{tabular}{|c|c|c|l|}
\hline S/N & Parental Role & $\begin{array}{c}\text { No of items } \\
\text { on PIQ }\end{array}$ & \multicolumn{1}{|c|}{ Description } \\
\hline 1 & Motivator & 5 & $\begin{array}{l}\text { Parents provide emotional support for } \\
\text { pipils' learning }\end{array}$ \\
\hline 2 & $\begin{array}{c}\text { Resource } \\
\text { Provider }\end{array}$ & 4 & $\begin{array}{l}\text { Parents play the role of resource } \\
\text { provider at home by providing an } \\
\text { appropriate place to study, relevant } \\
\text { reference books, and/or access to the } \\
\text { library }\end{array}$ \\
\hline 3 & $\begin{array}{c}\text { Mathematics } \\
\text { content Adviser }\end{array}$ & 4 & $\begin{array}{l}\text { Parents monitor their children's learning } \\
\text { and progress at home }\end{array}$ \\
\hline 5 & $\begin{array}{c}\text { Mathematics } \\
\text { learning } \\
\text { counselor }\end{array}$ & 5 & $\begin{array}{l}\text { Parents provide advice to their children } \\
\text { on mathematics content }\end{array}$ \\
\hline $\begin{array}{l}\text { Parents understand their children's } \\
\text { potential, needs and demands and } \\
\text { provide appropriate support to help their } \\
\text { children overcome learning difficulties. }\end{array}$ \\
\hline
\end{tabular}

Table 2: Brief Description of Parental Roles

The method of data analysis for this study involves the use of means, standard deviation and correlation analysis to answer research questions and the use of the $t$-test of significance of correlation to test the stated hypotheses at 0.05 level of significance. Extracts of the pupils' interview were also used to interpret the extent homes are involved in the mathematics education of their children, using qualitative data deduction techniques (Abakpa, Agbo-Egwu \& Abah, 2017).

\section{Results}

The results of this study are presented according to the research questions and hypotheses.

\section{Research Question One}

To what extent are homes in North Bank suburb of Makurdi, Nigeria, involved in the mathematics education of pupils at the Middle Basic level?

The results in Table 3 shows that, for pupils in the bottom category, there is low parental involvement with respect to item 1, item 7, item 9 and item 20. This implies that parents of pupils in the bottom category have problems supporting their children who are having difficulties in school mathematics. The parents of pupils in this category do not take their children to the library and lack in their houses variety of games, puzzles and activities that encourage the development of their children's mathematics skills. Likewise, they are not aware of the approaches used to teach mathematics in their children's schools. However, this category parents score high on all other items of the PIQ.

The results displayed in Table 4 indicate that parents of pupils in the top category are not aware of the approaches used to teach mathematics in their children's school (Item 20) and certainly lack mathematical games and puzzles in their houses (Item 9). Similarly, the parents of pupils in this category do not take their children to the Library (item 7). This category of parents also score low on item 1 of the PIQ. They however score high on the remaining items of the PIQ.

Considering that parents of pupils in both the bottom and top categories default on the same items of the PIQ, a comparison of the level of their involvement in terms of the five (5) parental roles is necessary. 
Abah J. A., Age T. J., Okoronkwo M. O. - ERIES Journal vol. 11 no. 2

\begin{tabular}{|c|c|c|c|c|}
\hline S/No. & PIQ Statement & Mean & SD & $\begin{array}{c}\text { Remarks (Level of Parental } \\
\text { Involvement) }\end{array}$ \\
\hline 1 & Statement 1 & 2.32 & 0.94 & Low \\
\hline 2 & Statement 2 & 3.09 & 0.79 & High \\
\hline 3 & Statement 3 & 3.05 & 0.81 & High \\
\hline 4 & Statement 4 & 3.44 & 0.66 & High \\
\hline 5 & ${ }^{*}$ Statement 5 & 2.85 & 0.82 & High \\
\hline 6 & Statement 6 & 2.71 & 0.84 & High \\
\hline 7 & Statement 7 & 2.05 & 0.78 & Low \\
\hline 8 & Statement 8 & 2.82 & 0.87 & High \\
\hline 9 & Statement 9 & 2.32 & 0.84 & Low \\
\hline 10 & Statement 10 & 3.00 & 0.89 & High \\
\hline 11 & *Statement 11 & 2.58 & 0.82 & High \\
\hline 12 & Statement 12 & 2.85 & 0.82 & High \\
\hline 13 & Statement 13 & 2.59 & 0.82 & High \\
\hline 14 & Statement 14 & 2.62 & 0.95 & High \\
\hline 15 & Statement 15 & 2.79 & 0.88 & High \\
\hline 16 & Statement 16 & 2.65 & 0.79 & High \\
\hline 17 & Statement 17 & 2.79 & 0.88 & High \\
\hline 18 & Statement 18 & 2.82 & 1.00 & High \\
\hline 19 & *Statement 19 & 2.65 & 0.81 & High \\
\hline 20 & Statement 20 & 2.41 & 0.78 & Low \\
\hline 21 & Statement 21 & 2.67 & 0.88 & High \\
\hline 22 & Statement 22 & 2.97 & 0.80 & High \\
\hline 23 & Statement 23 & 2.79 & 0.91 & high \\
\hline
\end{tabular}

\begin{tabular}{|c|c|c|c|}
\hline S/No. & $\begin{array}{c}\text { Parental } \\
\text { Role }\end{array}$ & $\begin{array}{c}\text { Cluster Mean of PIQ } \\
\text { Scores of Parents of Pupils } \\
\text { in Bottom Category }\end{array}$ & $\begin{array}{c}\text { Cluster Mean of PIQ } \\
\text { Scores of Parents of } \\
\text { Pupils in Top Category }\end{array}$ \\
\hline 1 & Motivator & 2.95 & 2.94 \\
\hline 2 & $\begin{array}{c}\text { Resource } \\
\text { Provider }\end{array}$ & 2.48 & 2.47 \\
\hline 3 & Monitor & 2.73 & 2.79 \\
\hline 4 & $\begin{array}{c}\text { Mathematics } \\
\text { Content } \\
\text { Advisor }\end{array}$ & 2.76 & 2.72 \\
\hline 5 & $\begin{array}{c}\text { Mathematics } \\
\text { Learning } \\
\text { Counselor }\end{array}$ & 2.70 & 2.74 \\
\hline & Grand Mean & 2.724 & 2.732 \\
\hline
\end{tabular}

\section{Table 5: Mean parental Involvement in the Five Key Parental Roles}

Out of all the pupils interviewed in this study, only three (3) answered "No" to the question "Do you like mathematics?" When asked why, one of the students replied "I don't like mathematics because it is too hard for me to understand". In the same vein, another student said"... because mathematics is a hard subject". The third student added "because mathematics is a hard subject and I always find it difficult to understand".

The pupils who accepted that they like mathematics gave reasons relating to future careers in Engineering, Accounting, Medicine, and other science-based disciplines. Some of the pupils actually opined that mathematics is simple and interesting. One of such pupils replied "because mathematics is a universal subject". Another pupil in this category said "because mathematics is very easy for me to solve". A pupil emphasized that "mathematics is a requisite subject which you must pass before gaining admission into the university".

When asked the question "Do you normally practice mathematics at home?" $23.3 \%$ of the pupils interviewed in this study answered "No", with the remaining $76.7 \%$ answering "Yes". Among the pupils that practice mathematics at home, the response to the prompt "who normally assist you in studying mathematics at home?" include "friend", "a sister", "neighbor", "father", "uncle", "cousin brother", "brother" and "mother". A pupil (Math score $=82$, position $=2^{\text {nd }}$ ) whose father normally assists in studying mathematics explained thus:

My father normally teaches me at home every day after the school hour. He uses good example and I follow the method he taught me.

Another pupil $\left(\right.$ Math score $=86$, Position $=1^{\text {st }}$ ) explained that his sister normally assist him in practicing mathematics at home. According to this pupil:

She normally asked me if there is any homework and if there is any, she teach me how to answer the question.

Table 4: Parental Involvement Score for Pupils in the Top Category The comparison in Table 5 shows that parents of pupils in the Bottom category are slightly better motivators, resource providers and mathematics content advisers than the parents of pupils in the Top category. On the other hand, parents of pupils in the Top category are better monitors and mathematics learning counselor than the parents of pupils of Bottom category. Ultimately, with a grand mean of 2.732 , homes of high achieving pupils are more involved in the mathematics education of their children than homes of low achieving pupils (grand mean = 2.724). The strength of these difference and relationship are tested in the hypotheses of this study.

A pupil (Math score $=40$, position $=15$ ) who replied that her neighbor assist him in studying mathematics at home explained: "I do ask her to explain and also to re-solve my class work for me". One of the pupils (Math score $=70$, position $=4^{\text {th }}$ ) who said her cousin brother normally assists her in studying mathematics at home reiterated thus: "He will ask me to solve the homework then he will later do the correction for me".

One of the pupils (Math score $=81$, position $=1^{\text {st }}$ ) said his cousin brother help him by solving his homework on the board in the house. Another pupil (Math score $=40$, Position $=21^{\text {st }}$ ) 
relate that his friend normally follow his mathematics note to teach him at home. A pupil (Math score $=70$, Position $=4^{\text {th }}$ ) whose brother usually assist in studying mathematics at home has this to say:

Whenever I solved any exercise from my textbook, I always show him for corrections. Sometimes I do give him some mathematics questions from my workbook to solve for me.

A pupil (Math score $=68$, Position $=9^{\text {th }}$ ) who is normally assisted by her brother explained how:

Whenever I come back from school, he will collect my mathematics book, then he will repeat the class work on a piece of paper and ask me to re-solve it. Then later, he will do the correction for me.

Another pupil $\left(\right.$ Math score $=70$, Position $=4^{\text {th }}$ ) explained that her uncle usually help her to solve mathematics questions that she was unable to solve. A pupil (Math score $=23$, position $=$ $30^{\text {th }}$ ) whose father normally assist in studying mathematics at home explained thus: "If I'm confused in any of the questions, I meet him and he explain details for me to understand".

In the same vein, a pupil (Math score $=52$, Position $=12^{\text {th }}$ ) usually assisted by his sister, explained thus:

She normally cross-check my notebook when I come home from school and ask me to repeat whatever my teacher taught me in the school.

When asked about strategies that could make them perform better in mathematics, the pupils pointed out extra home lessons, repeated practice, getting more mathematics textbooks and focusing more on what their teacher is teaching. One of the pupils (Math score $=44$, position $=16^{\text {th }}$ ) who earlier replied "I don't have anybody at home to assist me", ended his interview with "If I have someone around me to be assisting me I will perform better".

\section{Research Question Two}

What is the relationship between home involvement and mathematics achievement of Low-achieving pupils at the Middle Basic level in North Bank suburb of Makurdi, Nigeria.

\begin{tabular}{|c|c|c|c|c|}
\hline Variables & $\begin{array}{c}\text { No. of } \\
\text { pairs }\end{array}$ & $r$ & $\begin{array}{c}\text { SE } \\
\text { of } r\end{array}$ & Remarks \\
\cline { 1 - 4 } Home Involvement & \multirow{2}{*}{34} & 0.017 & 0.0177 & $\begin{array}{c}\text { Weak positive } \\
\text { correlation }\end{array}$ \\
\cline { 1 - 3 } Mathematics Achievement & &
\end{tabular}

Table 6: Correlation between Home Involvement (PIQ scores) and Mathematics Achievement (Math scores) of Pupils in the Bottom Category

The results in Table 6 indicate that there is a weak positive relationship $(r=0.017)$ between home involvement and mathematics achievement of low-achieving pupils at the Middle Basic level in North Bank suburb of Makurdi, Nigeria.

\section{Research Question Three}

What is the relationship between home involvement and mathematics achievement of high-achieving pupils at the middle Basic level in North Bank suburb of Makurdi, Nigeria?

\begin{tabular}{|c|c|c|c|c|}
\hline Variables & $\begin{array}{c}\text { No. of } \\
\text { pairs }\end{array}$ & $r$ & $\begin{array}{c}\text { SE } \\
\text { of } r\end{array}$ & Remarks \\
\cline { 1 - 4 } Home Involvement & \multirow{2}{*}{39} & 0.174 & 0.162 & $\begin{array}{c}\text { Weak positive } \\
\text { correlation }\end{array}$ \\
\cline { 1 - 3 } Mathematics Achievement & &
\end{tabular}

Table 7: Correlation between Home Involvement (PIQ scores) and Mathematics Achievement (Math scores) of Pupils in the Top Category

The result in Table 7 show that there is a weak positive relationship $(r=0.174)$ between home involvement and mathematics achievement of high achieving pupils at the Middle Basic level in North Bank suburb of Makurdi, Nigeria.

\section{Research Hypothesis One}

There is no significant difference between the level of home involvement in the mathematics education of low-achieving pupils and the level of home involvement in the mathematics education of high-achieving pupils at the Middle Basic level in North Bank suburb of Makurdi, Nigeria.

\begin{tabular}{|c|c|c|c|c|c|c|}
\hline Groups & $\mathrm{N}$ & Mean & SD & t. & $t$-critical & $p$-value \\
\hline Low Achievers & 34 & 2.731 & 0.293 & & & \\
\hline & & & & 0.113 & 1.9994 & $0.9102 *$ \\
\hline High Achievers & 39 & 2.746 & 0.332 & & & \\
\hline
\end{tabular}

* Not significant at $\alpha=0.05$

Table 8: Unpaired $t$-test of Home Involvement (PIQ Scores) of Low and High Achieving Pupils

The results in Table 8 indicate that there is no significant difference between the level of home involvement in the mathematics education of low-achieving pupils and the level of home involvement in the mathematics education of high achieving pupils at the Middle Basic level in North Bank suburb of Makurdi, Nigeria. This is because the $t$-value 0.113 is less than the $t$-critical value, 1.994 . Likewise, the $p$-value of 0.9102 is not significant at 0.05 level of significance.

\section{Research Hypothesis Two}

There is no significant relationship between home involvement and mathematics achievement of Low achieving pupils at the Middle Basic level in North Bank suburb of Makurdi, Nigeria.

\begin{tabular}{|c|c|c|c|c|}
\hline Variables & $\begin{array}{c}\text { No of } \\
\text { pairs }\end{array}$ & $r$ & $\begin{array}{c}\text { SE } \\
\text { of } r\end{array}$ & $p$-value \\
\cline { 1 - 4 } Home Involvement & \multirow{2}{*}{34} & 0.17 & 0.177 & $0.9241^{*}$ \\
\cline { 1 - 3 } Mathematics Achievement & & & \\
\hline
\end{tabular}

* Not significant at $\alpha=0.05$

Table 9: $t$-test of Correlation Coefficient between Home Involvement (PIQ scores) and Mathematics Achievement (Math Scores) of Pupils in the Bottom Category.

The results in Table 9 indicate that the $p$-value 0.9241 is not significant at 0.05 level of significance. Therefore, there is no significant relationship between home involvement and mathematics achievement of low-achieving pupils at the Middle Basic level in North Bank suburb of Makurdi, Nigeria.

\section{Research Hypothesis Three}

There is no significant relationship between home involvement and mathematics achievement of High achieving pupils at the Middle Basic level in North Bank suburb of Makurdi, Nigeria.

\begin{tabular}{|l|c|c|c|c|}
\hline \multicolumn{1}{|c|}{ Variables } & $\begin{array}{c}\text { No of } \\
\text { pairs }\end{array}$ & $r$ & $\begin{array}{c}\text { SE } \\
\text { of } r\end{array}$ & $p$-value \\
\cline { 1 - 4 } Home Involvement & 39 & 0.174 & 0.162 & $0.2884^{*}$ \\
\cline { 1 - 2 } Mathematics Achievement & & & 0.172 \\
\hline
\end{tabular}

$*$ Not significant at $\alpha=0.05$

Table 10: $t$-test of correlation coefficient between Home Involvement (PIQ scores) and Mathematics Achievement (Math scores) of Pupils in the Top Category 
The results in Table 10 show that the $p$-value $(0.2884)$ is not significant at 0.05 level of significance. Therefore, there is no significant relationship between home involvement and mathematics achievement of high-achieving pupils at the Middle Basic level in North Bank suburb of Makurdi, Nigeria.

\section{Discussions}

The outcome of this study reveals a systematic pattern of parents involvement in the mathematics education of their children, particularly at the Middle Basic level in North Bank suburb of Makurdi, Nigeria. Basically, the results in Table 3 and 4 affirm that parents and homes are adequately involved the mathematics education of Basic 5 pupils in the study area. This outcome supports the findings of Bicknell (2006). However, parents of pupils in both the high-achieving and low-achieving categories fare less in specific areas of supporting pupils who are having difficulties in school mathematics, taking their children to the public library and providing activities that encourage the development of their children's mathematics skills. Both categories of parents are not aware of the approaches used to teach mathematics in their children's school, suggesting a gap in the school-home relationship of pupil's mathematics education. These key findings reveal shortcomings on the part of the parents to turn everyday occurrences and household tasks into lessons that not only help pupils with their mathematical reasoning skills and sense of applied mathematics, but prepare them for adulthood (Kormanik, 2012). The observed gap in the schoolhome relationship with respect to the teaching and learning of mathematics may be due to schools and parents having a different understanding of what home involvement should look like. One of the best ways to structure this relationship is through involving parents in their children's home work and employing targeted parent involvement to solve a particular problem - such as poor attendance or behaviour at school (Dervarics \& O'Brien, 2011). In this regard, Basic schools can subscribe to the underlisted responsibilities in creating a partnership that can have a significant impact on pupils' achievement. Basic schools should:

i. Recognize that all parents, regardless of income, education or cultural background, are involved in their children's learning and want their children to do well in mathematics;

ii. Survey parents and the schools' teachers to understand their perspective on parent involvement. Investigate how parents want to be involved and how teachers want parents to be involved.

iii. Work to create a common understanding of how parents could best support their child's mathematics education and how teachers could communicate with parents. This might be accomplished through discussions, flyers, meetings or other strategies.

iv. Identify barriers to achievement within schools. Can parents help address these challenges? If so, how?

v. Give teachers training on how to develop homework assignments that involve parents.

vi. Regularly involve parents in their child's homework and report on the results of doing so.

(Dervarics \& O’Brien, 2011)

Considering the five key parental roles of parents of pupils in North Bank suburb, Table 5 indicates a low level of parents' involvement as mathematics resource provider for their wards. The cluster mean of 2.48 for parents of pupils in the Bottom category and the cluster mean of 2.47 for parents of pupils in the Top category both fall short of the benchmark mean of 2.50. this point to the fact that parents across all categories of mathematics learner at the Middle Basic level in North Bank suburb need to do more in making their homes conducive for learning mathematics. This entails making out time to take their children to the library and fostering a positive study culture at home. Parents can encourage their children's school work and providing books, mathematical equipment and a supportive home environment.

The extracts from pupils' responses to interview prompts from their mathematics teachers demonstrate that effective home engagement in the mathematics education of children gets the most out of their schooling. In line with the observations of Kwesi (2015), the pupils' responses reflect that parents, teachers and children consider mathematics as a hallmark of future success. These Basic 5 pupils could relate the importance of mathematics to their future career. Their responses revealed that home involvement in mathematics education is a collective affair in this part of the world, with members of the extended family, friends and neighbours playing vital roles. Such roles range from re-teaching class work at home to providing guidance for mathematics homework and exercises (Ulrychova, 2016).

This study also observed a weak positive relationship $(r=0.017)$ between home involvement and mathematics achievement of low achieving pupils at the Middle Basic level in North Bank suburb of Makurdi, Nigeria. A similar outcome $(r=0.174)$ was obtained for High achieving pupils at the Middle Basic level in North Bank suburb of Makurdi, Nigeria. However, it is noteworthy that although this similarity points to a unique characteristic of homes in the suburb (Jimenez Bandala \& Andrade, 2017; Husak \& Hudeckova, 2017; and Petr Safrankova \& Zaptopkova, 2017), the relationship is comparatively stronger for high achieving pupils. This finding is in tandem with the outcome of the work of Jackson and Remillard (2005) who observed that challenges in home involvement are due in part to the stereotypes held by schools in low income suburbs. The existing dynamics of homes in slum communities of Makurdi, such as the North Bank suburb, implies that home support in mathematics education of pupils is at best haphazard (Agada, 2017). The non-significance of the difference between the level of home involvement in the mathematics education of pupils across both low and high achieving categories points to homogeneity in home support practices in North Bank suburb. Similar outcomes shown in Table 9 and 10, lend more weight to this line of thought and support the view of Rockliffe (2001) that some parents as a homogenous group, generally lack confidence and expertise in harnessing the mathematics potentials of their children.

\section{Conclusion}

This study has attempted to verify the relationship between home involvement and mathematics achievement of pupils across both low and high achieving pupil - categories in North Bank suburb of Makurdi, Benue State, Nigeria. The survey of 73 Basic 5 pupils along with their parents across three (3) Middle Basic Schools in North Bank suburb establishes a weak positive relationship between home involvement and mathematics achievement that is homogenous to both achievement categories. Further interaction with the pupils reveals that apart from parents, other members of the extended family, friends and neigbours play vital roles in the mathematics education of children. The study also revealed that among the five key parental roles, parents of pupils in North Bank suburb have 
shortcomings as mathematics resources providers. This implies that they often default in providing a nice learning environment at home for their children to study mathematics. These homes lack variety of games, puzzles and activities that encourage the development of children's mathematics skills. They also failed in buying mathematics related books for the children and in taking their wards to the library.

Based on the findings of this study, the local School Home Partnership for Mathematics Education (SHPME) project intend to strategize with local schools in the North Bank suburb to develop an intervention programme for pupils already identified as seriously in need of home support. These efforts will be targeted at repositioning Basic schools in the study area to develop a working relationship with homes for the benefit of the children. Future studies in the course of this researchersponsored intervention will consider the viability of various approaches for educating both schools and homes on the mathematics education of children.

\section{Acknowledgements}

The author sincerely appreciates the collaboration of the three Mission Schools that participated in this study. Special thanks to Onoja Joseph Alexander (Methodist Nursery and Primary School, North Bank, Makurdi), Tse Wilfred (St. Mary's Nursery and Primary School, North Bank, Makurdi), and Iligh Simon Terzungwe (Children of Destiny - Assemblies of God - Nursery and Primary School, North Bank, Makurdi) for helping out as mathematics teachers and research assistants.

\section{References}

Abah, J.A. (2016) 'Recency bias in the era of big data: The need to strengthen the status of history of mathematics in Nigerian schools', Advances in Multidisciplinary Research Journal, vol. 2, no. 4, pp. 241-248.

Abah, J.A. (2017) 'Viewing basic math through the lens of history: Undergraduates' reflective learning in a historyaugmented mathematics classroom', Waikato Journal of Education, vol. 22, no. 4, pp. 33-48. http://dx.doi.org/10.15663/ wje.v22i4.557

Abakpa, B.O., Agbo-Egwu, A.O. and Abah, J.A. (2017) 'Emphasizing phenomenology as a research paradigm for interpreting growth and development in mathematics education', ABACUS: The Journal of the Mathematical Association of Nigeria, vol. 42, no. 1, pp. 391-405. http://dx.doi.org/10.17605/ OSF.IO/SGBZT

Adams, S.K. and Baronberg, J. (2011) Importance of family involvement. Pearson Allyn Bacon Prentice Hall, [online], Available: http://www.education.com/reference/article/ importance-family-involvement [15 Nov 2016].

Agada, J. (2017) Influence of the slum life on students' ability to understand mathematics at upper basic education level in Makurdi Local Government Area of Benue State. An unpublished B.Sc.Ed. Research Project submitted to the Department of Science Education, University of Agriculture, Makurdi. pp 1-59. Berkowitz, T., Schaeffer, M.W., Maloney, E.A., Peterson, L., Gregor, C., Levine, S.C. and Beilock, S.L. (2015) 'Math at home adds up to achievement in school', Science, vol. 350, no. 6257, pp. 196-198. http://dx.doi.org/10.1126/science.aac7427

Bibiire, R.A. and Omojokun, O.P.E. (2016) 'Parents involvement and community participation in improving educational quality', Ideal Journal of Education and Policy Studies, vol. 2, no. 1, pp. $15-22$.
Bicknell, B. (2006) 'Investigating parental roles of mathematically gifted students', In Proceedings of the 29th Annual Conference of the Mathematics Education Research Group of Australasia, Canberra, ACT Australia, Grootenboer, P., Zevenbergen, R. and Chinnappan, M. (eds.), Identities, Cultures and Learning Spaces, vol. 1, pp. 76-83.

Brown, L.L. (2016) Instill a love of math: Math tips for parents, PBS Parents, [online], Available: http://www.pbs.org/parents/ education/math/math-tips-for-parents/instill-a-love-of-math/ [17 Nov 2016].

Cai, J. (2003) 'Investigating parental roles in students' learning of mathematics from a cross-national perspective', Mathematics Education Research, vol. 15, no. 2, pp. 87-106. https://doi. org/10.1007/BF03217372

Coughlan, S. (2016) Why do Finnish pupils succeed with less homework?, BBC News, [online], Available: http://www.bbc. com/news/education-37716005 [15 Nov 2016].

CrumpledApps (2015) English dictionary offline. Version: 2.0.1. Devarics, C. and O'Brien, E. (2011) Back to school: How parent involvement affect students achievement (Full report). [online], Available: http://www.centerforpubliceducation.org/ research/back-school-how-parent-involvement-affects-studentachievement.html [11 Jul 2017].

Hartog, M.D. and Brosnan, P.A. (2008) Doing mathematics with your child. [online], Available: http://www.math.com/parents/ articles/domath.html [20 Nov 2016].

Husak, J. and Hudeckova, H. (2017) 'Conditions for development of rural community education in The Czech Republic', Journal on Efficiency and Responsibility in Education and Science, vol. 10, no. 3, pp. 64-70. http://dx.doi.org/10.7160/eriesj.2017.100301

Iji, C.O., Abah, J.A. and Anyor, J.W. (2017) 'Impact of cloud services on students' attitude towards mathematics education in public universities in Benue State, Nigeria', International Journal of Research in Education and Science (IJRES), vol. 3, no. 1 , pp. 228-244.

Iji, C.O., Abah, J.A. and Anyor, J.W. (2018) 'Educational Cloud Services and the Mathematics Confidence, Affective Engagement, and Behavioral Engagement of Mathematics Education Students in Public University in Benue State, Nigeria', International Journal of Teaching and Learning in Higher Education, vol. 30, no. 1, pp. 47-60.

Jackson, K. and Remillard, J.T. (2005) 'Rethinking parent involvement: African-American mothers construct their roles in the mathematics education of their children', The School Community Journal, vol. 15, pp. 51-74.

Jimenez-Bandala, C.A. and Andrade, L.A. (2017) 'Education, poverty and the trap of poor countries in the face of development', Journal on Efficiency and Responsibility in Education and Science, vol. 10, no. 4, pp. 101-108. http://dx.doi.org/10.7160/ eriesj.2017.100402

Kormanik, K. (2012) A greater role in math education: Mathematical reasoning at home, [online], Available: https:// edsource.org/2012/a-greater-role-in-math-education-forparents-mathematical-reasoning-at-home/23918 [20 Nov 2016].

Kwesi, Y.(2015) 'Parental involvement in children's mathematics learning: A case of a rural community, Ghana.' UBC Thesis and Dissertations. http://dx.doi.org/10.14288/1.0167193

LeFevre, J.-O., Skwarchuk, S.-L., Smith-Chant, B.L., Fast, L., Kamawar, D. and Bisanz, J. (2009) 'Home numeracy experiences and children's math performance in the early school years', Canadian Journal of Behavioural Science, vol. 41, no. 2, pp. 55-66. http://dx.doi.org/10.1037/a0014532 
Lingard, B., Hayes, D. and Mills, M. (2003) 'Teachers and productive pedagogies: Contextualising, conceptualising, utilizing', Pedagogy, Culture \& Society, vol. 11, no. 3, pp. 399424. https://doi.org/10.1080/14681360300200181

Lore, M.D., Wang, A.H. and Buckley, M.T. (2016) 'Effectiveness of a parent-child home numeracy intervention on urban Catholic school first grade students', Journal of Catholic Education, vol. 19, no. 3, pp. 142-165. http://dx.doi.org/10.15365/ joce. 1903082016

Petr Safrankova, A. and Zatopkova, K. (2017) 'Teachers' evaluation of importance of selected determinants of education of socially disadvantage pupils', Journal on Efficiency and Responsibility in Education and Science, vol. 10, no. 1, pp. 2433. http://dx.doi.org/10.7160/eriesj.2017.100104

Psychwiki.Com (2016) What is ex post facto design?, [online], Available: http://www.psychwiki.com/wiki/What_is_ex_postfacto_design \%3F [20 Nov 2016].

Rockliffe, F. (2001) Parental involvement in mathematics education in a Canadian elementary school, Paper presented at the European Research Network about Parents in Education. Netherlands: Rotterdam.

Ulrychova, J. (2016) 'Students' mathematics knowledge Theory and practice', Journal on Efficiency and Responsibility in Education and Science, vol. 9, no. 4, pp. 103-110. http:// dx.doi.org/10.7160/eriesj.2016.090403 